( П. О. Киричок, д.т.н., професор, Р. Л. Тріщук, аспірант, КПІ ім. Ігоря Сікорського, Київ, Україна

\title{
ПІДВИЩЕННЯ ЕКСПЛУАТАЦІЙНИХ ВЛАСТИВОСТЕЙ ДЕТАЛЕЙ ЛІНІЇ ДЛЯ ВИГОТОВЛЕННЯ ІНТЕГРАЛЬНИХ ОБКЛАДИНОК З ШИРОКИМ КЛАПАНОМ
}

У статті наведено аналітичний огляд методів зміцнення циліндричних металевих поверхонь деталей лінії для виготовлення інтегральних обкладинок з широким клапаном.

Значна частина відведена аналізу методів поверхневого пластичного деформування, до яких відносяться вібраційна обробка (вібродинамічне, вібраційне накатування, накатування профільним роликом), вигладжування надтвердими матеріалами, дорнування, розкатування та обкатування, дробоструменева обробка, електромеханічна пластична обробка, карбування.

Ключові слова: інтегральна обкладинка; регулярний мікрорельєф; вібраційне накатування; поверхневе пластичне деформування; методи зміцнення.

\section{Постановка проблеми}

Значна кількість деталей промислового обладнання працює в умовах підвищеної швидкості, навантаження i температури. Для забезпечення тривалої працездатності цих деталей використовують зазвичай високоміцні сталі та сплави, що спричиняє неабиякі витрати на дорогі матеріали й інструменти, якими ці деталі належить обробляти. Дефіцит матеріалів і брак оброблювальних інструментів спричиняє зниження ефективності виробництва та погіршує якість продукції. Для збільшення довговічності деталей застосовують різноманітні технологічні способи та методи їх поверхневого зміцнення [1]. В основному використовують такі методи обробки деталей як термічна, хіміко-термічна та фізико-хімічна обробка поверхонь деталей, поверхневе пластичне деформування, гальванічне покриття, напилення та наплавка поверхонь, електроіскрове легування тощо [2]. Проблема $є$ актуальною для поліграфічного машинобудування, а саме виготовлення та вдосконалення деталей друкарського обладнання. Для поліграфічного устаткування важливими вимогами $€$ підвищення якості вузлів та деталей, покращення їх експлуатаційних властивостей, а отже й збільшення надійності та терміну служби.

У покращенні технічних характеристик лінії для виготовлення інтегральних обкладинок 3 широким клапаном (ресурс роботи

(C) $2017 \mathrm{p}$. 
якої здебільшого визначається опором деталей машин різним видам контактної взаємодії) важливим є питання підвищення параметрів якості та експлуатаційних властивостей циліндричних поверхонь, що контактують. Від стабільної роботи вузлів тертя в лінії для виготовлення інтегральних обкладинок залежить не лише надійність цієї техніки, а й якість готової поліграфічної продукції. Утворення стабільного регулярного мікрорельєфу з одночасним зміцненням поверхневих шарів дає змогу збільшити термін служби циліндричних деталей лінії та їх експлуатаційні властивості. Це безпосередньо має позитивний вплив на якість кінцевої продукції завдяки зменшенню або уникненню таких негативних явищ як проковзування чи перекіс заготовок під час транспортування від самонакладу до склеювально-фальцювального блоку, що, як наслідок, призводить до нерівномірного та неточного нанесення клейового шару.

У зв'язку з цим актуальним $€$ вивчення та вибір технологічних процесів зміцнення поверхонь тертя циліндричних деталей лінії для виготовлення інтегральних обкладинок з широким клапаном.

\section{Аналіз попередніх досліджень}

На сьогодні для промислового обладнання, у тому числі й поліграфічного, існує багато способів і методів зміцнення металевих поверхонь деталей, що ґрунтуються на процесах їх оздоблювально-зміцнювальних обробок (ОЗО). Серед них:
- поверхневе пластичне деформування (ППД) [3-20];

- фізичні методи [21, 22];

- фізико-хімічні методи [2327];

- термічні та кріогенні методи [5, 28];

- хіміко-термічне поверхневе зміцнення [5, 29-32].

Усі ці методи мають свої переваги та недоліки й можуть застосовуватися як вибірково, так і комплексно. Для підвищення надійності роботи деталей друкарського обладнання пропонуються також методи, що поєднують оздоблювальні та зміцнювальні технології 3 нанесенням антикорозійних та інших видів покриття [6]. Застосування будьякого із цих методів передбачає певні обмеження з огляду на специфіку роботи деталей, їх фізико-хімічний склад та економічну доцільність застосування. Частина методів зміцнювальної обробки поверхонь металевих деталей може бути застосована відповідно до вимог поліграфічної галузі.

\section{Мета роботи}

Обґрунтувати вибір технологічного процесу зміцнення поверхневих шарів циліндричних деталей у поліграфічних машинах, який забезпечить високу якість поверхні та підвищить експлуатаційні властивості деталей лінії для виготовлення інтегральних обкладинок на основі аналізу попередніх теоретико-експериментальних досліджень.

\section{Результати проведених досліджень}

Найбільш поширеними в поліграфічному машинобудуванні $€$ 
методи поверхневого пластичного деформування, до яких належать вібраційна обробка (вібродинамічне та вібраційне накатування, накатування профільним роликом), вигладжування надтвердими матеріалами, дорнування, розкатування та обкатування, дробоструменева обробка, електромеханічна пластична обробка, карбування.

Вібродинамічне накатування процес утворення регулярних заглиблень, в основі якого лежить холодне пластичне деформування. Сполучення розкатувальної дії, характерної для більшості способів поверхневого пластичного деформування, з ударною дією $є$ особливістю цього способу зміцнення. У результаті поєднання вказаних дій частка залишкової деформації робочої поверхні зростає, що сприяє іїі істотному зміцненню як за ступенем, так і за глибиною залягання зміцненого шару металу. Режим вібродинамічного накатування визначається такими параметрами як частота обертання диска з кульками, подача, кількість подвійних ходів, амплітуда [7]. Хоча цей спосіб вважають універсальним і продуктивним, він має окремі недоліки, до яких слід віднести дискретний характер утворюваних заглиблень (що погіршує умови протікання мастил), односторонній динамічний вплив на заготовку й елементи верстата (що обмежує його застосування для обробки мало- і нерівножорстких деталей, призводить до зниження жорсткості верстатів, появи шуму).

Накатування профільним роликом - спосіб зміцнення, що ґрунтується на перенесенні мік- рорельєфу інструмента-ролика на заготовку. Тобто мікрорельєФ видавлюється на вузькій ділянці поверхні деталі, яка не перевищує ширини ролика [10]. Основна перевага цього способу - висока продуктивність, але через суттєві недоліки (дороговизна і складність виготовлення інструменту, застосування значних зусиль при обробці) сфера застосування цього методу зміцнення обмежується серійним і великосерійним виробництвами відносно малотвердих сталей.

Вібраційне накатування вважається найбільш універсальним методом зміцнення поверхневих шарів металу з одночасним утворенням на поверхні регулярних мікрорельєфів. Цей метод базується на тонкому пластичному деформуванні поверхневих шарів металу й складному відносному переміщенні оброблюваної деталі та деформувального елемента. Способи утворення регулярних мікрорельєфів за цільовим призначенням розподіляють на дві групи: способи, за допомогою яких на поверхні утворюється частково регулярний мікрорельєф, і способи, що дозволяють утворювати повністю новий регулярний мікрорельєф. У першому випадку на поверхні утворюються безперервні або дискретно розташовані заглиблення, між якими залишається вихідна шорсткість, у другому повністю новий мікрорельєф з однаковими за формою, висотою і взаємним розташуванням нерівностями. Вібраційне накатування найбільше застосовують при обробці зовнішніх і внутрішніх циліндричних поверхонь. Режим вібронакатування характеризу- 
ється такими параметрами як частота обертання заготовки, подача деформувального елемента за один оберт заготовки, кількість осциляцій деформувального елемента, амплітуда осциляцій, діаметр заготовки, зусилля вдавлювання деформувального елемента, радіус сфери деформувального елемента $[3,4,14]$.

Цей метод зменшує шорсткість, дозволяє отримувати потрібні параметри мікрорельєфу, глибину зміцнення поверхневого шару, мікротвердість поверхні. Завдяки застосуванню вібраційного накатування також забезпечуються необхідні параметри мікрорельєфу та якості поверхневих шарів, що сприяє покращенню фізико-механічних та експлуатаційних властивостей, а також геометричних параметрів робочих поверхонь друкарського циліндра й обтяжки [12].

До недоліків методу вібронакатування слід віднести значну складність обробки протяжних поверхонь малих діаметрів, це пов'язано з невеликими розмірами деформувальних елементів, амплітуд осциляційного руху та зусиль вібронакатування.

Вигладжування надтвердими матеріалами - це метод зміцнювальної обробки, який полягає в пластичному деформуванні оброблюваної поверхні ковзанням по ній інструментом-вигладжувачем. При цьому нерівності поверхні, які залишились від попередньої обробки, частково або повністю згладжуються, поверхня набуває дзеркального блиску, підвищується твердість поверхневого шару, у якому утворюються стискувальні залишкові напруги, змінюється мікроструктура та формується направлена структура-текстура. Після вигладжування поверхня залишається чистою, не шаржованою уламками абразивних зерен. Таке поєднання якостей вигладженої поверхні визначає її високі експлуатаційні властивості - стійкість до зношування, опір утомленості тощо. На шорсткість впливають такі параметри процесу вигладжування як зусилля вигладжування, подача та радіус робочої частини інструмента. У результаті пластичної деформації при алмазному вигладжуванні зміцнюється поверхневий шар металу, зокрема збільшується твердість, межа пружності та текучості, проте зменшується його пластичність $[9,17]$. Недоліком способів вигладжування $\epsilon$ низька продуктивність обробки, оскільки вони здійснюються занадто вузькими поздовжніми або поперечними рядками (шириною близько 0,1 мм). Основною перепоною на шляху до підвищення ефективності алмазного вигладжування є прямо пропорційна залежність температури в зоні контакту й швидкості процесу. Тому важливим завданням $\epsilon$ вивчення впливу параметрів режиму обробки на енергосилові характеристики процесу та стійкість інструмента.

Дорнування $€$ ефективним способом оздоблювально-зміцнювальної обробки отворів. При дорнуванні підвищується міцність пресових посадок і довговічність деталей, що мають концентратори напруг у вигляді поперечних отворів. Оздоблювально-зміцнювальна обробка дорнуванням дозволяє в деяких випадках 
виключити з технологічного процесу розгортання, хонінгування та термічні операції. При дорнуванні пластичні деформації охоплюють усю товщину стінки оброблюваної деталі, діаметр отвору заготовок змінюється до необхідних розмірів, поліпшуються фізико-механічні властивості й оброблюваність матеріалу. Дорнування застосовують здебільшого для обробки великих партій деталей та для досягнення низької шорсткості їх поверхні.

Розкатування та обкатування - зміцнювальний метод, під час застосування якого оброблюються циліндричні зовнішні та внутрішні, наскрізні та глухі, пласкі поверхні, галтелі ступінчастих, колінчастих і шліцьових валів, бокові поверхні черв'яків. Обкатування застосовується в усіх видах виробництва для обробки деталей машин, виготовлених із сирих і загартованих сталей, чавунів і кольорових сплавів. Операція здійснюється за допомогою роликів, кульок або інших деформувальних інструментів, закріплених у пристроях на токарних, свердлильних та інших універсальних або спеціальних верстатах. Пристрої з обкатувальними кульками дозволяють створити більш інтенсивну пластичну деформацію за менших зусиль обкатування. У зв'язку з цим кулькові розкатні й обкатні пристрої можна рекомендувати для обробки твердих матеріалів і деталей 3 малою жорсткістю в поліграфічному машинобудуванні. Пристрої з обкатними кульками рекомендуються також для обробки малогабаритних поверхонь та отворів малого діаметру. Недоліками розкатування $є$ необхідність точної попередньої обробки заготовок 3 урахуванням зминання мікронерівностей і зміни остаточного розміру деталі. Численність проходів інструмента та надмірний тиск руйнують поверхню і можуть призвести до відшарування іiї окремих ділянок. До недоліків обкатування слід віднести: невелику абсолютну величину залишкових напружень; обробку при малих подачах (0,06-0,47 мм/об), що збільшує час зміцнення; залежність якості обробки від властивостей оброблюваного матеріалу, стану вихідної поверхні та режимів обкатування.

Дробоструменева обробка метод зміцнення, суть якого полягає в пластичному деформуванні поверхневого шару деталі шляхом прямої ударної дії мікрокульок дробу, які подаються струменем на великій швидкості. Причому твердість дробу має дещо перевищувати твердість оброблюваного матеріалу. Під час будь-яких способів дробоструменевої обробки на ступінь зміцнення впливають: швидкість дробу при зустрічі з оброблюваною поверхнею; розмір, якість і витрати дробу; тривалість обробки; напрям струму дробу кут атаки; щільність, з якою дріб вкриває оброблювану ділянку поверхні; відстань оброблюваної поверхні від місця вильоту дробу та фізико-механічні властивості металу оброблюваної деталі. Цей вид зміцнення зручний для обробки деталей та інструментів складної конфігурації. Під час такої обробки розміри деталей практично не змінюються, залишаючись у межах поля допуску [5]. До недоліків дробо- 
струменевої обробки слід віднести невелику глибину зміцнення, нагрівання деформованої поверхні від ударів твердих дробинок, які летять 3 великою швидкістю, невисоку щільність і рівномірність потоку дробу, що впливає на однорідність й суцільність зміцнення. Для цього методу зміцнення поверхонь необхідне спеціалізоване устаткування.

Електромеханічна пластична обробка - це процес електромеханічної обробки металу, який можна реалізувати електромеханічним згладжуванням або електромеханічною висадкою. При електромеханічному пластичному зміцненні здійснюється вплив тиску інструмента на оброблювану деформувальним інструментом поверхню і тепла, що виникає в результаті проходження електричного струму між інструментом і деталлю. Це спричиняє зміцненню завдяки поліпшенню фізико-механічних властивостей поверхневого шару та параметрів мікрорельєфу самої поверхні. Цей спосіб ефективний для зміцнення сталей з великим умістом вуглецю. Недоліки - надмірна шорсткість обробленої поверхні, теплові впливи на метал за жорстких режимів.

Карбування застосовують зазвичай для обробки габаритних i важких деталей, особливо галтелей масивних валів. Процес карбування здійснюється шляхом направленого ударного впливу на оброблювану поверхню за допомогою спеціального бойка, направлений удар якого допомагає зміцнити внутрішні кути, шпонкові канавки, шліцьові вали, галтелі, канавки, виточки, фаски отворів різних деталей складної конфігурації, що не піддаються зміцненню шляхом обкатки або дробоструменевої обробки.

\section{Зміцнення поверхонь}

фізичними методами

Лазерне зміцнення (загартування) здійснюється шляхом високотемпературного лазерного нагрівання поверхні або ділянок поверхні металевої деталі з подальшим швидким охолодженням. Лазерне загартування має деякі особливості, що вигідно вирізняють його 3-поміж інших методів зміцнення: локальність процесу зміцнення (за глибиною та площею), можливість обробки у важкодоступних місцях, отримання заданої шорсткості поверхні, отримання визначених фізико-механічних, хімічних та інших властивостей поверхонь оброблюваних деталей шляхом їх легування різними елементами, можливість автоматизації процесу тощо. Сфера застосування лазерного зміцнення - підвищення стійкості різального інструменту, прес-форм, вирубних штампів, поршнів, штоків, плунжерів, розподільних колінчастих валів двигунів внутрішнього згоряння, зубчастих коліс тощо. Зміцнення відбувається при впливі імпульсного та безперервного лазерного випромінювань [18, $21,22]$. Зміцненню піддаються вуглецеві, маловуглецеві та леговані, високолеговані, низьковуглецеві, хромисті корозійно стійкі, швидкорізальні сталі.

\section{Фізико-хімічні методи}

зміцнення поверхонь

Для відновлення таких деталей як поліграфічний вал, друкарський 
циліндр, підшипник кочення в друкарській секції застосовують спосіб газоплазмового нанесення порошкових матеріалів з одночасним їх оплавленням, оскільки він дозволяє отримати тверді, зносостійкі поверхневі шари з різних матеріалів [23-25].

Наплавка як процес зміцнення дозволяє підвищити стійкість деталей проти абразивного зношування, ерозії, електрохімічної корозії, кавітаційного руйнування, окалиноутворення, термічної та контактної втоми; дозволяє замінити в деталях високолеговані сталі вуглецевими, а кольорові метали - чорними. Методи наплавки використовують для відновлення й одночасного зміцнення зношених деталей. Найбільше розповсюдження отримали такі способи наплавки: вібродугова наплавка, наплавка під шаром флюсу, наплавка в середовищі діоксиду вуглецю, наплавка порошкового дроту без флюсового або газового захисту, плазмова наплавка. Недоліки - залишкові напруження розтягу, які утворюються при нанесенні покриттів і $€$ одним 3 основних факторів, що знижують працездатність зміцнених деталей.

Електрохімічне зміцнення метод отримання покриттів з металевою або полімерною матрицею, армованою дисперсними частками. Зміцнення здійснюється шляхом осаду порошкових покриттів на робочі поверхні сталевих деталей складної конфігурації - такої як деталі прес-форм, штампів, мірного інструменту, різного технологічного оснащення.

Нікелювання, хромування, електрохімічне зміцнення, електрохімічне полірування є найбільш розповсюдженими методами електрохімічного зміцнення. Нікелювання застосовують для підвищення зносостійкості робочих поверхонь деталей машин і механізмів, збільшення довговічності, захисту поверхонь від корозії, пошкоджень і заїдань, стійкості до кислот і лугів. Процес хромування застосовується для підвищення стійкості й відновлення деталей машин, механізмів, різального, контрольного й вимірювального інструментів, а також формоутворювальних елементів штампів, прес-форм, діркопробивних пуансонів і матриць. Покриття хромом наносять на деталі масою до 700 кг, утім більшість деталей зазвичай мають масу до 1 кг. Довжина деталей, що хромуються, може сягати 10 м, а діаметр робочої поверхні - 3 м. Однак найчастіше довжина деталей становить 10-200 мм. Здебільшого деталі виготовляють з легованих і вуглецевих сталей, що піддаються хромуванню. Недоліки хромових покриттів низький вихід за струмом, мала швидкість осадження хрому, велика трудомісткість процесу та висока вартість. Істотними недоліками електрохімічного полірування є складність забезпечення рівномірного зняття металу з різних ділянок деталі, мала точність обробки та незначне зменшення розмірів великих нерівностей погано оброблених поверхонь. Для методу анодної електрохімічної обробки негативною $€$ висока електропровідність розчинів електролітів, що призводить до низької локалізації процесу знімання металу та його розчинення не тільки в призначеній зоні, а й у прилеглих до неї 
ділянках поверхні деталі. Суттєвим недоліком катодної електрохімічної обробки можна вважати те, що під час проведення процесу в стаціонарних гальванічних ваннах його тривалість $є$ дуже великою, до того ж, за таких умов ймовірною $€$ можливість виникнення шорсткостей.

Іонно-плазмове зміцнення процес, за якого речовину осаджуваного металу у вакуумі послідовно перетворюють на газ, пару, іонізовану пару та плазму й осаджують в атмосфері реакційного або нейтрального газу у вигляді конденсату на зміцнювану поверхню. Отримують покриття методом термічного випаровування, катодного або іонно-плазмового розпилення або шляхом бомбардування поверхні іонами речовини, що осаджується. Як реакційний газ використовують азот або вуглекислий газ. Відповідно покриття складається з нітритних або карбідних сполук тугоплавких металів. Процеси іонно-плазмової обробки здійснюють переважно у вакуумних установках. Зміцнення методами іонно-плазмової обробки застосовують для підвищення зносостійкості інструментів, а також відповідальних сталевих деталей машин, що працюють в умовах адгезійного та дифузійного зношування при високих температурах сполучених середовищ. У джерелах [23, $24,26]$ наведено методи поверхневого зміцнення деталей машин плазмовим пучком та подано практичні рекомендації для добору режимів і технологічних варіантів зміцнення. Недоліки цього виду зміцнення - високі питомі потужності споживання електроенергії, а також відносно тривалий цикл процесу.
Електроіскрова обробка - метод зміцнення, суть якого полягає в легуванні поверхневого шару металу виробу (катода) матеріалом електрода (анода) при електроіскровому розряді в повітряному середовищі. У результаті хімічної реакції легувального матеріалу з дисоційованим атомарним азотом і вуглецем повітря, а також 3 матеріалом зміцнюваної деталі в поверхневих шарах утворюються загартовані структури й складні хімічні сполуки (високодисперсні нітриди, карбонітриди й карбіди), унаслідок чого формується дифузійний зміцнений шар, який має високу твердість і зносостійкість.

Зміцненню цим методом піддають поверхні деталей машин та механізмів типу направляючих, клинців, фіксаторів, кулачків, зажимів тощо, поверхні шпонкових пазів, шліців, отвори корпусних деталей, виготовлених 3 конструктивних легованих і вуглецевих сталей. Електроіскрове зміцнення застосовують для підвищення зносостійкості та твердості поверхні деталей машин, що працюють за підвищених температур в інертних газах, жаростійкості та корозійної стійкості поверхні, збільшення розмірів зношених деталей машин та механізмів при ремонті, утворення шорсткості під наступне гальванічне покриття, полегшення паяння звичайним припоєм матеріалів, що важко паяються. Недоліки методу - порівняно низька продуктивність, швидко руйнується інструмент - електрод.

Хімічний осад з розчинів включає декілька типових методів: фосфатування, нікель-фосфатування, 
нікель-борування, нікель-кобальтфосфатування, хімічне нікелювання, епіламіювання, зміцнення твердими мастилами. Фосфатування здійснюють для захисту від корозії та підвищення стійкості поверхонь різального інструменту типу протяжок, розгорток, фрез, різців, свердел, зенкерів, плашок, мітчиків, деталей машин і механізмів, що працюють на стирання. Нікель-фосфатування здійснюється для покращення різальних якостей і стійкості інструментів шляхом покриття їх елементів із швидкорізальних сталей зносостійкими плівками нікель-фосфату. Нікель-борування застосовують для підвищення зносостійкості, твердості та корозійної стійкості металу. Мета зміцнення нікель-кобальт-фосфатуванням - підвищення зносостійкості й антифрикційних якостей сталевих деталей складної конфігурації, що працюють в умовах тертя при підвищених температурах (прес-форми, мірний інструмент, поршні) [18]. Хімічне нікелювання - комплексне багатошарове хімічне осадження $з$ допомогою нікелевмісного розчину з можливою подальшою термічною обробкою. Епіламіювання застосовують для підвищення стійкості поверхонь деталей машин, механізмів i, особливо, для збільшення стійкості інструментів усіх типів, що використовують при різанні металів, штампуванні, витяжці, прокатці, пресуванні тощо. Зміцнення твердими мастилами застосовують, коли необхідно підвищити стійкість різальних, волочильних та інших інструментів. Недоліки більшості процесів хімічного осаду з розчинів полягають у довготривалості обробки сталевих деталей, значній кількості операцій, що супроводжуються витратами матеріалів.

\section{Термічні та кріогенні методи}

Термічне зміцнення. До цих видів зміцнення належать відпал, нормалізація, загартування, відпуск, поліпшення, старіння, а також кріогенна обробка. Процес відпалу проходить при нагріванні деталі до заданої температури та подальшій витримці за цієї температури з поступовим повільним охолодженням. Відпал буває рекристалізаційний, повний, неповний, ізотермічний, низькотемпературний, дифузійний (гомогенізація) і відпал на зернистий перліт (сфероїдизація). Зміцнення відпалом поліпшує механічні властивості, вирівнює хімічний склад сталі, зменшує залишкові деформації, здійснює підготовку структури сталі для подальшої термічної обробки та поліпшує її оброблюваність на верстатах. Нормалізація процес нагрівання сталі до певної температури, витримка при цій температурі з подальшим охолодженням на повітрі. Загартуванням називають процес, під час якого сталь нагрівають до заданої температури і після витримування при цій температурі швидко охолоджують у воді, оливі або на повітрі залежно від складу сталі. Після загартування сталь стає твердою та крихкою. Відпуск - процес нагрівання і витримування загартованої сталі за температури на 20-30 С нижчій за критичну. У результаті відпуску підвищується в'язкість і пластичність сталі. Поліпшення процес загартування з наступним 
високим відпуском, його результатом $€$ досягти необхідного поєднання міцності та в'язкості. До недоліків термічного зміцнення слід віднести труднощі з регулюванням товщини загартованого шару.

Кріогенний метод зміцнення. Суть цього методу полягає в глибокому охолодженні, у результаті якого поліпшуються механічні властивості інструментів, у тому числі інструментів з швидкорізальних сталей, підвищуються твердість і зносостійкість контрольно-вимірювальних інструментів, штампів і прес-форм, що виготовляються 3 високовуглецевих і легованих конструкційних сталей, збільшується твердість корозійностійких матеріалів з підвищеним вмістом вуглецю. Кріогенна обробка конструкційних сталей не є доцільною, оскільки температура кінця мартенситного перетворення таких сталей вища $20^{\circ}$ C. Цей вид обробки застосовують для конструкційних сталей, які попередньо пройшли цементацію, азотування або ціанування.

\section{Хіміко-термічне поверхневе}

\section{зміцнення}

Цементація - хіміко-термічна обробка, що полягає в дифузійному насиченні поверхневого шару сталі вуглецем при нагріванні у відповідному середовищі карбюризаторі. Після цементації проводиться термічна обробка загартування та низький відпуск. У результаті цих процесів отримують поверхневий шар високої твердості, підвищуються його теплостійкість, зносостійкість та межа витривалості. Цьому різновиду зміцнення піддають низьковуглецеві сталі, у яких після цементації та загартування утворюється в'язка серцевина [18].

Нітроцементація - процес зміцнення, що характеризується дифузійним насиченням поверхневого шару сталі одночасно вуглецем і азотом в газовому або рідинному середовищі, яке складається з насиченого вуглецем газу та аміаку. Цей вид зміцнення сприяє підвищенню твердості та зносостійкості сталевих виробів, а також поліпшує їх механічні властивості. Нітроцементації зазвичай піддають деталі складної конфігурації, схильні до жолоблення [18].

Азотування - вид хіміко-термічної обробки, під час якої відбувається дифузійне насичення поверхневого шару азотом. Процес триває в аміачному середовищі при нагріванні деталі до 480-650 С. Азотуванню зазвичай піддають конструкційні сталі, корозійностійкі жароміцні, інструментальні та штампувальні сталі. У результаті застосування цього виду обробки підвищуються поверхнева твердість і зносостійкість, межі витривалості, а також корозійна й ерозійна стійкість виробів. Недоліком азотування $€$ крихкість азотованого шару та повільність самого процесу, який триває зазвичай до 60 год $[18,33]$.

Борування - процес, що являє собою хіміко-термічне зміцнення поверхневого шару заліза, під час якого здійснюється його дифузійне насичення бором у відповідно нагрітому середовищі. Борування застосовують для підвищення зносостійкості деталей машин і механізмів, особливо 
для тих, що працюють в агресивних та абразивних середовищах, а також за підвищених температур. Поверхневий шар, насичений бором, характеризується підвищеною корозійною стійкістю, теплостійкістю, високою твердістю, стійкістю проти зношування. Боруванню можуть підлягати будь-які сталі, але найчастіше цей спосіб застосовують для низьковуглецевих сталей. Стійкість деталей, що підлягають боруванню, зростає у 2-10 разів [30, 31]. Недоліки борування: підвищена крихкість шару, при гартуванні можливі тріщини.

Аналіз досліджень способів зміцнення, що проводились у цьому напрямі, з урахуванням матеріалів, 3 яких зроблено циліндричні деталі вузлів лінії для виготовлення інтегральних обкладинок 3 широким клапаном, а також інших параметрів, засвідчив, що найбільш перспективним $€$ впровадження комплексної технології зміцнення, яка поєднує процеси вібраційної оздоблювально-зміцнювальної обробки з подальшим нанесенням антикорозійного покриття.

Запропонована технологія передбачає два етапи:

- перший - утворення на поверхні деталі частково-регулярного мікрорельєфу методом вібраційного обкатування;

- другий - нанесення на поверхню деталі шару хрому.

Застосування вібраційного обкатування на першому етапі комплексної обробки процесу обумовлено універсальністю цього методу зміцнення поверхневих шарів металу з одночасним утворенням на поверхні регулярних мікрорельєфів. Метод базується на тонкому пластичному деформуванні поверхневих шарів металу й складному відносному переміщенні оброблюваної деталі та деформувального елемента.

За рахунок одночасного незалежного варіювання значень великої кількості параметрів режиму вібраційного обкатування стає можливим утворення регулярних мікрорельєфів різних видів і, при цьому, практично необмежено змінюються та регулюються значення як стандартизованих, так і нестандартизованих геометричних параметрів якості поверхні.

Застосування на другому етапі захисного покриття у вигляді шару хрому дозволить збільшити стійкість і довговічність сталевих деталей та є ефективним методом зниження втрат металу внаслідок корозії.

\section{Висновки}

Кожен із розглянутих нами методів має ті чи інші переваги та недоліки й може застосовуватися самостійно або в комплексі з іншими методами. Запропонована комплексна технологія оздоблювально-зміцнювальної обробки поверхні методом вібраційного обкатування з подальшим її хромуванням дозволить суттєво збільшити термін служби циліндричних деталей лінії для виготовлення інтегральних обкладинок, збільшить стійкість і довговічність сталевих деталей, їх корозійну стійкість i, як результат, вплине на підвищення якості кінцевої продукції.

Перспективність і доцільність вібраційної оздоблювально-зміцнювальної обробки з подальшим 
нанесенням антикорозійного покриття пояснюється широкими технологічними можливостя- ми та суттєвими техніко-економічними перевагами над іншими методами.

\section{Список використаної літератури}

1. Гавриш А. П. Зміцнення металевих поверхонь деталей машин та механізмів / А. П. Гавриш, П. О. Киричок, М. П. Підберезний. Київ: Наук. думка, 1995. $174 \mathrm{C}$.

2. Ляшенко Б. А. Тенденции развития упрочняющей поверхностной обработки и положение в Украине / Б. А. Ляшенко, С. А. Клименко // Сучасне машинобудування. 1999. № 1(1). С. 94-104.

3. Рыжов Э. В. Повышение контактной жесткости деталей вибронакатыванием / Э. В. Рыжов, А. Г. Суслов // Станки и инструменты. 1978. № 1. С. 77-78.

4. Одинцов Л. Г. Упрочнение и отделка деталей поверхностным пластическим деформированием: справочник / Л. Г. Одинцов. М.: Машиностроение, 1987. 327 с.

5. Киричок П. О. Зміцнення поверхонь металевих деталей / Киричок П. О., Олійник В. Г., Киричок Т. Ю. Київ: Преса України, 2004. 240 с.

6. Лотоцька О. І. Підвищення експлуатаційних властивостей деталей поліграфічних машин / О. І. Лотоцька // Технологія і техніка друкарства. 2008. № 3-4. C. 16-20. Режим доступу: http://ttdruk.vpi.kpi.ua/article/view/58790.

7. Балтер М. А. Упрочнение деталей машин / М. А. Балтер. М.: Машиностроение, 1978. 184 с.

8. Горохов В. А. Обработка деталей пластическим деформированием / В. А. Горохов. Киев: Техника, 1978. 192 с.

9. Одинцов Л. Г. Финишная обработка деталей алмазным выглаживанием и вибровыглаживанием / Л. Г. Одинцов. М.: Машиностроение, 1981. 160 с.

10. Папшев Д. Д. Отделочно-упрочняющая обработка поверхностным пластическим деформированием / Д. Д. Папшев. М.: Машиностроение, 1978. $152 \mathrm{c.}$

11. Папшев Д. Д. Упрочнение деталей обкаткой шариками / Д. Д. Папшев. М.: Машиностроение, 1968. 132 с.

12. Зигуля С. Підвищення надійності деталей поліграфічного обладнання вібраційним накатуванням / С. Зигуля // 11-й міжнародний симпозіум українських інженерів-механіків у Львові: тези доповідей, 15-17 травня 2013 року, Львів / Національний університет «Львівська політехніка» [та інші]. Львів: КІНПАТРІ ЛТД, 2013. С. 164-165.

13. Пшибыльский М. Технология поверхностной пластической обработки / М. Пшибыльский. М.: Металлургия, 1991. 479 с.

14. Шнейдер Ю. Г. Эксплуатационные свойства деталей с регулярным микрорельефом / Ю. Г. Шнейдер. Л.: Машиностроение, 1982. 248 с.

15. Шнейдер Ю. Г. Эксплуатационные свойства деталей с регулярным рельефом поверхности, полученным виброобкатыванием / Г. Шнейдер // Вестник машиностроения. 1971. № 2. С. 59-61.

16. Шнейдер Ю. Г. Новый государственный стандарт на поверхности с регулярным микрорельефом / Ю. Г. Шнейдер, Ю. П. Кузьмин, В.М.Сорокин и др. // Вестник машиностроения. 1982. № 4. С.73-74.

17. Шульман П. А. Качество поверхности, обработанной алмазами / П. А. Шульман, Ю. И. Сузин, Н. Ф. Колесниченко, А. С. Вишневский. Киев: Техніка, 1972. $148 \mathrm{c}$.

18. Фесенко А. Г. Методи поверхневого зміцнення у процесі виготовлення деталей машин: навч. посіб. / А. Г. Фесенко та ін. Дніпропетровськ: РВВ ДНУ, 2015. 104 с. 
19. Алексеев Г. А. Динамика нанесения прецизионного микрорельефа / Г. А. Алексеев. Л.: Изд-во Ленингр. ун-та, 1986. 184 с.

20. Васильева А. Г. Деформационное упрочнение закаленных конструкционных сталей / А. Г. Васильева. М.: Машиностроение, 1981. 231 с.

21. Коваленко В. С. Обработка материалов импульсным излучением лазеров / В. С. Коваленко. Киев: Вища школа, 1977. 144 с.

22. Дубнюк В. Л. Результати застосування чисельних методів вирішення рівняння теплопровідності при проектуванні операцій лазерної поверхневої обробки деталей друкарських верстатів / В. Л. Дубнюк, О. П. Худякова, В. П. Котляров // Технологія і техніка друкарства. 2014. № 4(46). С. 52-70. Режим доступу: http://ttdruk.vpi.kpi.ua/article/view/39162.

23. Соснин Н. А. Плазменные покрытия (технология и оборудование) / Н. А. Соснин, П. А. Тополянский, Б. Вичик. СПб: Знание, 1992. 28 с.

24. Соснин Н. А. Повышение стойкости деталей машин и инструмента методом плазменно-дугового упрочнения / Н. А. Соснин, П. А. Тополянский, С. А. Ермаков // Станки и инструмент. 1990. № 11. С. 38-39.

25. Гордеев А. С. Восстановление деталей полиграфического оборудования методом газоплазменного нанесения порошковых материалов / А. С. Гордеев, А. Г. Басова // Вісник НТУ «ХП|». 2010. № 46. С. 36-40.

26. Лещинский Л. К. Плазменное поверхностное упрочнение / Л. К. Лещинский, С. С. Самотугин, И. И. Пирч, В. И. Комар. Київ: Техника, 1990. 109 с.

27. Бурумкулов Ф. Х. Электроискровые технологии восстановления и упрочнения деталей машин и инструментов (теория и практика) / Ф. И Бурумкулов др. Саранск: Красный Октябрь. 2003. 504 с.

28. Термическая обработка в машиностроении: справочник / под ред.

Ю. М. Лахтина, А. Г. Рахштадта. М.: Машиностроение, 1980. 783 с.

29. Костецкий Б. И. Поверхностная прочность материалов при трении / Б. И. Костецкий, И. Г. Носовский, А. К. Караулов, Л. И. Бершадский. Киев: Техника, 1978. 296 с.

30. Эпик А. П. Исследование свойств диффузионных карбидных и боридных покрытий на конструкционных сталях / А. П. Эпик, Е. Н. Шавловский, Е. А. Миронов и др. // Фізико-хімічна механіка матеріалів. 1979. Т. 14. № 5. C. $67-70$.

31. Мишин В. Н. Исследование износостойкости борированой стали / В. Н. Мишин, Е. В. Шадричев // Докл. 25 юбил. науч.-технич. конф. Сев.Зап. заочн. политех. Ин-та. Л., 1981. С. 40- 44.

32. Назаренко П. В. Исследование износостойкости керамических покрытий, работающих в гидроабразивной среде / П. В. Назаренко, А. Е. Ненастьина // Новое в технологии ремонта воздушных судов на заводах гражданской авиации. Киев: КИИГА, 1992. С. 39-43.

33. Лахтин Ю. М. Азотирование сталей / Ю. М. Лахтин, Я. Д. Коган. М.: Машиностроение, 1976. 256 с.

\section{References}

1. Havrysh, A. P., Kyrychok, P. O. \& Pidbereznyi, M. P. (1995). Zmitsnennia metalevykh poverkhon detalei mashyn ta mekhanizmiv [Strengthening of metal surfaces of machine parts and mechanisms]. Kyiv: Naukova dumka, 174 [in Ukrainian].

2. Lyashenko, B. A. \& Klimenko, S. A. (1999). Tendentsii razvitiya uprochnyayushchey poverkhnostnoy obrabotki i polozhenie $v$ Ukraine [Trends in the development of strengthening surface treatment and the situation in Ukraine]. Journal of Suchasne mashynobuduvannia, 1(1), 94-104 [in Russian]. 
3. Ryzhov, E. V. \& Suslov, A. G. (1978). Povyshenie kontaktnoy zhestkosti detaley vibronakatyvaniem [Increase of contact stiffness of parts by vibro-draining]. Journal of Stanki i instrumenty, 1, 77-78 [in Russian].

4. Odintsov, L. G. (1987). Uprochnenie i otdelka detaley poverkhnostnym plasticheskim deformirovaniem: spravochnik [Hardening and finishing of parts by surface plastic deformation: reference book]. Moscow: Mashinostroenie, 327 [in Russian].

5. Kyrychok, P. O., Oliinyk, V. H. \& Kyrychok, T. Iu. (2004). Zmitsnennia poverkhon metalevykh detalei [Strengthening of metal parts surfaces]. Kyiv: Presa Ukrainy, 240 [in Ukrainian].

6. Lototska, O. I. (2008). Pidvyshchennia ekspluatatsiinykh vlastyvostei detalei polihrafichnykh mashyn [Increase of operational properties of details of printing machines]. Journal of Tekhnolohiia i tekhnika drukarstva - Technology and Technique of Typography, 3-4, 16-20. Kyiv: VPI NTUU 'KPI'. Retrieved from http://ttdruk.vpi.kpi.ua/article/view/58790 [in Ukrainian].

7. Balter, M. A. (1978). Uprochnenie detaley mashin [Hardening of machine parts]. Moscow: Mashinostroenie, 184 [in Russian].

8. Gorokhov, V. A. (1978). Obrabotka detaley plasticheskim deformirovaniem [Processing of parts by plastic deformation]. Kiev: Tekhnika, 192 [in Russian].

9. Odintsov, L. G. (1981). Finishnaya obrabotka detaley almaznym vyglazhiva-niem i vibrovyglazhivaniem [Finishing of details by diamond smoothing and vibration shaving]. Moscow: Mashinostroenie, 160 [in Russian].

10. Papshev, D. D. (1978). Otdelochno-uprochnyayushchaya obrabotka poverkhnostnym plasticheskim deformirovaniem [Finishing-hardening treatment by surface plastic deformation]. Moscow: Mashinostroenie, 152 [in Russian].

11. Papshev, D. D. (1968). Uprochnenie detaley obkatkoy sharikami [Hardening of details with running-in of balls]. Moscow: Mashinostroenie, 132 [in Russian].

12. Zyhulia, S. (2013). Pidvyshchennia nadiinosti detalei polihrafichnoho obladnannia vibratsiinym nakatuvanniam [Increasing reliability of parts of printing equipment by vibrating rolling]. Journal of 11-i mizhnarodnyi sympozium ukrainskykh inzheneriv-mekhanikiv u Lvovi: - 11th International Symposium of Ukrainian Mechanical Engineers in Lviv. Lviv: KINPATRI LTD, 164-165 [in Ukrainian].

13. Pshibyl'skiy, M. (1991). Tekhnologiya poverkhnostnoy plasticheskoy obrabotki [Technology of surface plastic processing]. Moscow: Metallurgiya, 479 [in Russian].

14. Shneyder, Yu. G. (1982). Ekspluatatsionnye svoystva detaley s regulyarnym mikrorel'efom [Operational properties of parts with regular microrelief]. Leningrad: Mashinostroenie, 248 [in Russian].

15. Shneyder, G. (1971). Ekspluatatsionnye svoystva detaley s regulyarnym rel'efom poverkhnosti, poluchennym vibroobkatyvaniem [Operational properties of parts with a regular surface relief obtained by vibratory rolling]. Journal of Vestnik mashinostroeniya, 2, 59-61 [in Russian].

16. Shneyder, Yu. G., Kuz'min, Yu. P., Sorokin, V. M. \& etc. (1982). Novyy gosudarstvennyy standart na poverkhnosti s regulyarnym mikrorel'efom [New state standard on a surface with a regular microrelief]. Journal of Vestnik mashinostroeniya, 4, 73-74 [in Russian].

17. Shul'man, P. A., Suzin, Yu. I., Kolesnichenko, N. F. \& Vishnevskiy, A. S. (1972). Kachestvo poverkhnosti, obrabotannoy almazami [The quality of the surface treated with diamonds]. Kiev: Tekhnika, 148 [in Russian].

18. Fesenko, A. H. \& etc. (2015). Metody poverkhnevoho zmitsnennia u protsesi vyhotovlennia detalei mashyn [Methods of surface hardening in the process of manufacturing machine parts]. Dnipropetrovsk: RVV DNU, 104 [in Ukrainian]. 
19. Alekseev, G. A. (1986). Dinamika naneseniya pretsizionnogo mikrorel'efa [Dynamics of precision of microrelief]. Leningrad: Izd-vo Leningr. un-ta, 184 [in Russian].

20. Vasil'eva, A. G. (1981). Deformatsionnoe uprochnenie zakalennykh konstruktsionnykh staley [Deformation hardening of hardened structural steels]. Moscow: Mashinostroenie, 231 [in Russian].

21. Kovalenko, V. S. (1977). Obrabotka materialov impul'snym izlucheniem lazerov [Processing of materials by pulsed laser radiation]. Kiev: Vishcha shkola, 144 [in Russian].

22. Dubniuk, V. L., Khudiakova, O. P. \& Kotliarov, V. P. (2014). Rezultaty zastosuvannia chyselnykh metodiv vyrishennia rivniannia teploprovidnosti pry proektuvanni operatsii lazernoi poverkhnevoi obrobky detalei drukarskykh verstativ [Results of numerical methods for solving the heat equation in the design of laser surface treatment operations details printing presses]. Journal of Tekhnolohiia i tekhnika drukarstva - Technology and Technique of Typography, 4(46), 52-70. Retrieved from http://ttdruk.vpi.kpi.ua/article/view/39162 [in Ukrainian].

23. Sosnin, N. A., Topolyanskiy, P. A. \& Vichik, B. (1992). Plazmennye pokrytiya (tekhnologiya i oborudovanie) [Plasma coatings (technology and equipment)]. Sankt-Peterburg: Znanie, 28 [in Russian].

24. Sosnin, N. A., Topolyanskiy, P. A. \& Ermakov, S. A. (1990). Povyshenie stoykosti detaley mashin i instrumenta metodom plazmenno-dugovogo uprochneniya [Increasing the durability of machine and tool parts by the method of plasma arc hardening]. Journal of Stanki $i$ instrument, 11, 38-39 [in Russian].

25. Gordeev, A. S. \& Basova, A. G. (2010). Vosstanovlenie detaley poligraficheskogo oborudovaniya metodom gazoplazmennogo naneseniya poroshkovykh materialov [Restoration of details of printing equipment by the method of gas-plasma application of powder materials]. Journal of Visnik NTU 'KPI', 46, 36-40 [in Russian].

26. Leshchinskiy, L. K., Samotugin, S. S., Pirch, I. I. \& Komar, V. I. (1990). Plazmennoe poverkhnostnoe uprochnenie [Plasma surface hardening]. Kyiv: Tekhnika, 109 [in Russian].

27. Burumkulov, F. I. \& etc. (2003). Elektroiskrovye tekhnologii vosstanovleniya i uprochneniya detaley mashin i instrumentov (teoriya i praktika) [Electrospark technologies for the restoration and hardening of machine parts and tools (theory and practice)]. Saransk: Krasnyy Oktyabr', 504 [in Russian].

28. (1980). Termicheskaya obrabotka v mashinostroenii [Heat treatment in mechanical engineering]. Moscow: Mashinostroenie, 783 [in Russian].

29. Kostetskiy, B. I., Nosovskiy, I. G., Karaulov, A. K. \& Bershadskiy, L. I. (1978). Poverkhnostnaya prochnost' materialov pri trenii [Surface strength of materials in friction]. Kiev: Tekhnika, 296 [in Russian].

30. Epik, A. P., Shavlovskiy, E. N., Mironov, E. A. \& etc. (1979). Issledovanie svoystv diffuzionnykh karbidnykh i boridnykh pokrytiy na konstruktsionnykh stalyakh [Investigation of the properties of diffusion carbide and boride coatings on structural steels]. Journal of Fiziko-khimichna mekhanika materialiv, vol. 14, 5, 67-70 [in Russian].

31. Mishin, V. N. \& Shadrichev, E. V. (1981). Issledovanie iznosostoykosti borirovanoy stali [Investigation of the wear resistance of boron steel]. Journal of Dokl. 25 yubil. nauch.-tekhnich. konf. Sev.-Zap. zaochn. politekh. In-ta, 40-44. Leningrad [in Russian].

32. Nazarenko, P. V. \& Nenast'ina, A. E. (1992). Issledovanie iznosostoykosti keramicheskikh pokrytiy, rabotayushchikh $v$ gidroabrazivnoy srede [Study of the 
wear resistance of ceramic coatings operating in a waterjet medium]. Journal of Novoe $v$ tekhnologii remonta vozdushnykh sudov na zavodakh grazhdanskoy aviatsii, 39-43. Kiev: KIIGA [in Russian].

33. Lakhtin, Yu. M. \& Kogan, Ya. D. (1976). Azotirovanie staley [Nitriding of steels]. Moscow: Mashinostroenie, 256 [in Russian].

В статье представлен аналитический обзор методов упрочнения цилиндрических металлических поверхностей деталей линии для изготовления интегральных обложек с широким клапаном. Особое внимание уделено анализу методов поверхностного пластического деформирования,

к которым относятся вибрационная обработка (вибродинамическая, вибрационное накатывание, накатывание профильным роликом), выглаживание сверхтвердыми материалами, дорнование, раскатывание и обкатывание, дробеструйная обработка, электромеханическая пластическая обработка, чеканка.

Ключевые слова: интегральные обложки; регулярный микрорельеф; вибрационное накатывание; поверхностное пластическое деформирование; методы упрочнения.

An analytical review of the strengthening methods for cylindrical metal surfaces of line workpieces for flexible covers with a wide valve production is given in the article. The particular emphasis is paid to the analysis of surface plastic deformation methods. The methods of such kind include vibration processing (vibrodynamic rolling, vibration rolling, profile burnishing), burnishing

by extrahard materials, mandrelling, rolling, shotblasting processing, electromechanical plastic processing, stamping.

Keywords: flexible covers; regular microrelief; vibration rolling; surface plastic deformation; methods of strengthening.

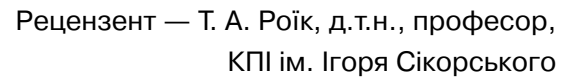
КП। ім. Ігоря Сікорського 